\title{
DL-3-n-butylphthalide improved physical and learning and memory performance of rodents exposed to acute and chronic hypobaric hypoxia
}

\section{Gang Xu}

Army Medical University

\section{Yikun Shi}

Army Medical University

\section{Binda Sun}

Army Medical University

Lu Liu

Army Medical University

\section{Guoji E}

Army Medical University

\section{Shu He}

Army Medical University

Jianyang Zhang

Army Medical University

\section{Bao Liu}

Army Medical University

Qiu Hu

Army Medical University

Jian Chen

Army Medical University

\section{Yuqi Gao}

Army Medical University

Erlong Zhang ( $\sim$ loong0810@sina.com )

Third Military Medical University https://orcid.org/0000-0003-4940-3516

\section{Research}

Keywords: DL-3-n-butylphthalide, hypobaric hypoxia, physical function, cognitive function, oxidative stress, energy metabolism 
Posted Date: August 10th, 2020

DOI: https://doi.org/10.21203/rs.3.rs-39309/v2

License: (c) (i) This work is licensed under a Creative Commons Attribution 4.0 International License. Read Full License

Version of Record: A version of this preprint was published on March 25th, 2021. See the published version at https://doi.org/10.1186/s40779-021-00314-7. 


\section{Abstract}

Background: Studies revealed the protective effect of DL-3-n-butylphthalide (NBP) against ischemic hypoxia diseases. However, the role of NBP in animals with hypobaric hypoxia is elusive. This study investigated the effect of NBP on animals with acute and chronic hypobaric hypoxia.

Methods: SD rats and Kunming mice administrated with NBP ( 90, 180 and $360 \mathrm{mg} / \mathrm{kg}$ for mice, 60, 120, and $240 \mathrm{mg} / \mathrm{kg}$ for rats and 90,180 and $360 \mathrm{mg} / \mathrm{kg}$ for mice 60,120 , and $240 \mathrm{mg} / \mathrm{kg}$ for rats ) were placed located in 10,000 $\mathrm{m}$ hypobaric hypoxia chamber. And survival analysis of animals implied that NBP could significantly improve and survival percent at $30 \mathrm{~min}$ were analyzed . Then, drug treated animals rats (mice) were evaluated for exhaustive exhausted time and exhaustive exhausted distance in forced exercise wheel-track treadmill and treadmill running and motor-driven wheel-track treadmill experiments at $5,800 \mathrm{~m}(5,000 \mathrm{~m})$ for 3 or 21 days or 21 days, to evaluate changes of physical functions. Rats were also evaluated for times of active escape, and average time of active escape, time of passive escape, and average time of passive escape in a shuttle-box experiment at 5,800 $\mathrm{m}$ for 7 days or 28 days 7 or 28 days, to evaluate changes of cognitive learning and memory function s. ATP level was evaluated measured in the gastrocnemius muscle and maloaldehyde (MDA), superoxide dismutase (SOD), hydrogen peroxide ( $\mathrm{H} 2 \mathrm{O} 2$ ), lactate, and glutathione peroxiase (GSH-Px) measurements and routine blood tests were detected in serum of rats .

Results: Survival analysis in 10,000 m indicated NBP could improve hypoxia tolerance ability. Exhaustive Exhausted time for rats (NBP, 120 and $240 \mathrm{mg} / \mathrm{kg}$ ) and exhaustive exhausted time and distance for mice (NBP, $90 \mathrm{mg} / \mathrm{kg}$ ) significantly increased under acute hypoxia. And NBP treatment also significantly increased the exhaustive exhausted time for rats under chronic hypoxia. Moreover, NBP of 120 and 240 $\mathrm{mg} / \mathrm{kg}$ significantly increased the average time s of passive active escape under acute and chronic hypoxia. These results suggested that NBP could improve physical and cognitive learning and memory functions under acute and chronic hypobaric hypoxia. Furthermore, the levels of MDA and $\mathrm{H} 2 \mathrm{O} 2$ decreased but those of SOD and GSH-Px in serum of rats increased under acute and chronic hypoxia. Furthermore, Additionally, the content of ATP in gastrocnemius muscle significantly increased, while lactate in serum level significantly decreased. The results presented suggested that NBP could regulate redox homeostasis and improve energy metabolism of hypobaric hypoxic rats.

Conclusion: NBP could improve physical and cognitive learning and memory functions under acute and chronic hypobaric hypoxia by increasing anti-oxidative capacity and energy supply.

\section{Background}

Exposure to high altitude environment may lead to an obvious decrease in work and cognitive performances [1,2]. At an altitude of $4,500 \mathrm{~m}$, the maximum working capacity was found to reduce to $50 \%$ of that observed at low altitude [2]. People exposed to hypobaric hypoxia conditions showed significant alterations in cognitive processes, including attention, short-term memory, decision-making, simple and 
complex reaction time, and mood [1]. The changes in physical and cognitive functions in response to hypobaric hypoxia may greatly affect work and normal life. Therefore, development of drugs and methods to alleviate physical and cognition impairment is imperative for migrators in high altitude.

High altitude acclimatization is the physiological process comprises a number of responses by different system in the body, which takes place in the body on exposure to hypoxia at plateau. Many studies have revealed that changes involved in acclimatization occur in various systems and with varying systems and with varying time courses. Many people can maintain homeostasis needed for body function through acclimatization at a low oxygen partial pressure $[3,4]$. However, acute and chronic high altitude illness will occur in people who exposed in high with a poor acclimatization and greatly damage diverse abilities $[5,6]$. Therefore, studying the molecular mechanism for high altitude diseases will provide pathways to elevate human abilities at high altitude. Current studies found that disorders of inflammation response [7], metabolism [8] and oxidative stress [9] were closely associated with high altitude illnesses. Agents that modulated these processes will show a potential to improve human activities under high altitude.

DL-3-n-butylphthalide (NBP), a racemic mixture of an optical isomer extracted from the seeds of Apium graveolens Linn (Figure 1), is widely used to treat patients with ischemic stroke [10]. NBP is thought to inhibit inflammation and oxidative as well as endoplasmic reticulum stress and promote angiogenesis in cerebral ischemic animals and patients [11]. NBP was recently shown to exert neuroprotective effects by alleviating vascular cognitive impairment [12] and promoting neuroplasticity and motor recovery after cerebral ischemia [13] and chronic intermittent hypoxia-hypercapnia [14]. Whether NBP exerts beneficial effects in other hypoxic conditions, such as hypobaric hypoxia is, however, unclear.

In this work, we investigated the effects of NBP on the physical and cognitive abilities of rodents in hypobaric hypoxia conditions (equivalent to $5,800 \mathrm{~m}$ ). The role of NBP on animal behavior was evaluated through exhausted exercise and shuttle-box experiments. We evaluated the potential mechanism of NBP by collecting muscle and blood samples from treated animals and analyzing the levels of ATP, malonaldehyde (MDA), superoxide dismutase (SOD), hydrogen peroxide $\left(\mathrm{H}_{2} \mathrm{O}_{2}\right)$, lactate, and glutathione peroxidase (GSH-Px) as well as by performing routine blood tests.

\section{Materials And Methods}

\subsection{Experimental animals and NBP administration}

Male pathogen-free Sprague-Dawley (SD) rats (6 to 8 weeks old, weighing 180-220 g) and male pathogen-free Kunming (KM) mice ( 6 weeks old, weighting 18-20 g) were used in this study. Rats and mice were obtained from the Laboratory Animal Center of Army Medical University, and the animal study protocol was approved by the Animal Care and Use Committee Guidelines of the Army Medical University. NBP (purity, 99.6\%) was obtained from Shijiazhuang Pharma Group NBP Pharmaceutical Co., Ltd (Shijiazhuang, Hebei, China). Animals were randomly assigned to four experimental groups as follows: control group (equivalent volume corn oil), NBP low dose-treated group $(60 \mathrm{mg} / \mathrm{kg}$ for rats and $90 \mathrm{mg} / \mathrm{kg}$ 
for mice), NBP intermediate dose-treated group (120 mg/kg for rats and $180 \mathrm{mg} / \mathrm{kg}$ for mice), and NBP high dose-treated group ( $240 \mathrm{mg} / \mathrm{kg}$ for rats and $360 \mathrm{mg} / \mathrm{kg}$ for mice). NBP was intragastrically administered once or twice every day. Animals had free access to food and water.

\subsection{Acute hypoxia survival experiment in 10,000 m hypobaric hypoxia chamber [15]}

The purpose of this experiment was to evaluate the effect of NBP on hypoxia tolerance ability of rats and mice under acute hypobaric hypoxia. NBP were given to SD rats and KM mice by intragastric administration at $1 \mathrm{ml} / 100 \mathrm{~g}$ body weight for 7 days at $300 \mathrm{~m}$ altitude (Chongqing altitude). After 1.14 hours from last administration, animals were placed in hypobaric hypoxia chamber. The high altitude of chamber ascended to $10,000 \mathrm{~m}$ by around $1,000 \mathrm{~m} / \mathrm{min}$. The survival of animals were observed and recorded and the experiment stopped at $30 \mathrm{~min}$ in 10,000 $\mathrm{m}$ (Figure 2).

\subsection{Standard hypoxia tolerance experiment of mice [15]}

This experiment was used to evaluate the effect of NBP on hypoxia tolerance ability of mice under normobaric hypoxia. NBP were given to KM mice by intragastric administration for 3, 5, or 7 days. After 1.14 hours from last administration, each mouse was put into a bottle with $125 \mathrm{ml}$ volume and $5 \mathrm{~g}$ of soda lime added, which was used to absorb the carbon dioxide and water vapor produced by breathing. Then, the lid was tightly sealed until the mouse's breathing movement stopped. The ST, i.e., the time from when the mouse was sealed in the bottle to its death, was recorded (Figure 2). STT was calculated according to formulas [16].

$\mathrm{STT}=\mathrm{ST} /(\mathrm{V}-\mathrm{BW} / 0.94)$

STT: standard hypoxia tolerance time $(\mathrm{min} / \mathrm{ml}), \mathrm{ST}$ : survival time ( $\mathrm{min})$, V: bottle volume $(\mathrm{ml})$, BW: body weight of mice $(\mathrm{g})$.

\subsection{Treadmill running experiment for acute hypoxic rats}

This experiment was used to evaluate the effect of NBP on physical ability of rats under acute hypobaric hypoxia. NBP was intragastrically administered to SD rats for 3 days at $300 \mathrm{~m}$ altitude. Rats were then subjected to treadmill exercise everyday as follows: $5 \mathrm{~min}$ for adaptation, followed by $15 \mathrm{~m} / \mathrm{min}$ for 10 min and $20 \mathrm{~m} / \mathrm{min}$ for $20 \mathrm{~min}$. On day 4, rats were placed in a 5,800 m hypobaric hypoxia chamber, administrated NBP and subjected to the above exercise regimen for 3 days. On day 7, exhausted test was conducted by a treadmill running experiment after NBP administration at 5,000 m altitude. The experimental plan included $5 \mathrm{~min}$ for adaptation, followed by $15 \mathrm{~m} / \mathrm{min}$ for $3 \mathrm{~min}, 20 \mathrm{~m} / \mathrm{min}$ for $3 \mathrm{~min}, 25$ $\mathrm{m} / \mathrm{min}$ for $24 \mathrm{~min}$, and then $30 \mathrm{~m} / \mathrm{min}$ up to exhausted status [17]. And the running time was used to evaluate physical ability under acute hypoxia exposure. Rats were anaesthetized and their arterial blood was collected for the analysis of MDA, SOD, $\mathrm{H}_{2} \mathrm{O}_{2}$, lactate, and GSH-Px levels as well as to perform routine blood tests. In addition, the gastrocnemius muscle tissues was excised and used for ATP detection. MDA, SOD, $\mathrm{H}_{2} \mathrm{O}_{2}$, lactate, and GSH-Px levels were detected by Nanjing Jiancheng assay agents 
(A003-1, A001-3, A064-1-1, A020-1-2, and A005, respectively). ATP level was analyzed by a Beyotime ATP assay kit (S0026). Blood routine tests were performed at the Xinqiao Hospital, Chongqing, China (Figure 2).

\subsection{Motor-driven wheel-track treadmill experiments for acute hypoxic mice}

This experiment was used to evaluate the effect of NBP on physical ability of mice under acute hypobaric hypoxia. KM mice were intragastrically treated with NBP twice per day for 6 days at low altitude. On day 4, mice were exercised on a motor-driven wheel-track treadmill (YLS-10B, Shandong Academy of Medical Sciences, Jinan, China) for 3 days at 5,000 $\mathrm{m}$ altitude under following conditions: $10 \mathrm{~min} /$ day, electronic shock current: $0.8 \mathrm{~mA}$, electronic shock time: $3 \mathrm{~s}, 30 \mathrm{~s}$ rest after electronic shock, and five times rest in 10 min as exhausted standard [18]. On the day 7 , mice were performed exhausted test on the motor-driven wheel-track treadmill $1.14 \mathrm{hr}$ after NBP administration at 5,000 $\mathrm{m}$ altitude and exhausted distance was recorded (Figure 2).

\subsection{Treadmill running experiment for chronic hypoxic rats}

This experiment was used to evaluate the effect of NBP on physical ability of rats under chronic hypobaric hypoxia. Rats were placed in 5,800 m hypobaric hypoxia chamber and intragastrically administered with NBP for 14 days from day 8. Rats were exercised on treadmill as above for 3 days from day 18 . On day 21, exhausted test was conducted in treadmill running experiment. At exhausted status, rats were anaesthetized and their arterial blood samples were obtained to analyze MDA, SOD, $\mathrm{H}_{2} \mathrm{O}_{2}$, lactate, and GSH-Px levels and perform routine blood test. Further, gastrocnemius muscle was excised for ATP detection (Figure 3).

\subsection{Shuttle-box experiment for acute hypoxic rats}

To investigate NBP on the learning and memory ability of acute hypoxia, the behavior of rats was evaluated by a shuttle box (RD1106-SB-R, Shanghai Mobile Datum Information Technology Company, Shanghai, China). NBP was intragastrically administered to SD rats for 7 days in $5,800 \mathrm{~m}$ hypobaric hypoxia chamber. On day 4, rats were subjected to an exercise process. Each rat underwent 50 trials daily after a five-minute adaptation period. Rats were exposed to a 10-second sound and light followed by a 10-second foot shock $(2.2 \mathrm{~mA})$ and 10-second interval in each trial. If the rat moved to the other chamber within sound and light onset, the behavior was counted as active escape and the sound and light was turned off with no exposure to foot shock. The time from active escape to expected foot shock was regarded as active escape time. If it did not change chambers during a trial, the behavior was counted as error and the rat received a 10-second foot shock. In each trial, times (frequency) and time of active escape were used as the measure for the learning and memory ability [19]. On day 7 , active escape times and time of rats were record (50 trials) in the shuttle-box experiment in 5,000 m hypobaric hypoxia chamber. Rats were then anaesthetized and their arterial blood was collected to measure MDA, SOD, $\mathrm{H}_{2} \mathrm{O}_{2}$, and GSH-Px levels (Figure 2). 
This experiment was used to evaluate the effect of NBP on learning and memory ability of rats under chronic hypobaric hypoxia. Rats were placed in 5,800 m hypobaric hypoxia chamber and administered with NBP via intragastric route for 21 days from day 8 . From day 25, rats were subjected to the exercise process mentioned above for 3 days. On day 28, active escape times and time of rats were record was measured (50 trials) by the shuttle-box experiment. At the end of the experiment, rats were anaesthetized and arterial blood was collected for the analysis of MDA, SOD, $\mathrm{H}_{2} \mathrm{O}_{2}$, and GSH-Px levels (Figure 3).

\subsection{Statistical analysis}

Statistical analysis was carried out using the SPSS 19.0 software. For survival analysis, a Kaplan-Meier curve was generated using the log-rank test. Other experiments were analyzed using an independentsamples $t$ test. A value of $p<0.05$ was considered statistically significant.

\section{Results}

\subsection{NBP could improve hypoxia tolerance ability of rats and mice}

To investigate whether NBP could benefit animals in hypobaric hypoxia, we firstly studied the effect of NBP on the survival time at 10,000 m exposure with 30 min as stopped time. The survival curve of experiments showed that 120 and $240 \mathrm{mg} / \mathrm{kg} \mathrm{NBP}$ administration could significantly improve the survival time of rats instead of mouse (Figure 4A, B). Compared to control group (rat $100 \%$, mouse $81.25 \%$ ), the death percent at $30 \mathrm{~min}$ in 120 (90\%) and $240 \mathrm{mg} / \mathrm{kg}$ group (80\%) for rats and $180 \mathrm{mg} / \mathrm{kg}$ group (62.5\%) for mice was declined (Figure 4C, D). Moreover, the standard tolerance time with closed hypoxia (control group, $12.18 \pm 2 \mathrm{~min} / 100 \mathrm{ml} \cdot \mathrm{g}, 360 \mathrm{mg} / \mathrm{kg}$ group, $13.94 \pm 1.54 \mathrm{~min} / 100 \mathrm{ml} \cdot \mathrm{g}, p=0.046$ ) (Figure S1) of mice also markedly extended by $360 \mathrm{mg} / \mathrm{kg}$ NBP administration for day 5 . The results indicated that NBP could improve the ability of hypoxia tolerance of rats and mice.

\subsection{NBP improved physical ability under acute and chronic hypoxia}

As hypobaric hypoxia is known to impair physical and cognitive functions in humans, we studied the role of NBP on the physical and cognitive behaviors of animals. The physical abilities of rats and mice were evaluated through treadmill running and motor-driven wheel-track treadmill experiments.

Under acute hypoxic conditions, NBP treatment at 120 and $240 \mathrm{mg} / \mathrm{kg}$ concentrations significantly increased the exhausted time of rats (control group, $38.28 \pm 17.85 \mathrm{~min}, 120 \mathrm{mg} / \mathrm{kg}$ group, $61.8 \pm 19.3 \mathrm{~min}$, $p=0.027,240 \mathrm{mg} / \mathrm{kg}$ group, $73.26 \pm 26.89 \mathrm{~min}, p=0.001)$, and $90 \mathrm{mg} / \mathrm{kg}$ NBP dose significantly improved the exhausted time (control group, $6.79 \pm 8.72 \mathrm{~min}, 90 \mathrm{mg} / \mathrm{kg}$ group, $16.79 \pm 14 \mathrm{~min}, p=0.02$ ) and distance (control group, $101.62 \pm 130.78 \mathrm{~m}, 90 \mathrm{mg} / \mathrm{kg}$ group, $251.49 \pm 210.07 \mathrm{~m}, p=0.02$ ) for mice (Figure 5). Moreover, NBP at 60,120 , and $240 \mathrm{mg} / \mathrm{kg}$ concentrations could significantly increase the exhausted time for rats under chronic hypoxia (control group, $38.59 \pm 16.83 \mathrm{~min}, 60 \mathrm{mg} / \mathrm{kg}$ group, $66.83 \pm 28.1 \mathrm{~min}$, 
$p=0.024,120 \mathrm{mg} / \mathrm{kg}$ group, $75 \pm 32.34 \mathrm{~min}, p=0.008,240 \mathrm{mg} / \mathrm{kg}$ group, $79.1 \pm 26.33 \mathrm{~min}, p=0.001$ ) (Figure 6). These results suggest that NBP may improve the physical ability of animals under acute and chronic hypoxia.

To clarify the mechanism underlying the NBP-mediated acceleration in physical activity under acute and chronic hypoxic conditions, we evaluated the levels of MDA, SOD, $\mathrm{H}_{2} \mathrm{O}_{2}$, lactate, and GSH-Px in the blood and ATP in the gastrocnemius muscle of rats. The levels of MDA (control group, $38.83 \pm 19.59 \mathrm{nmol} / \mathrm{ml}$, $60 \mathrm{mg} / \mathrm{kg}$ group, $16.89 \pm 14.48 \mathrm{nmol} / \mathrm{ml}, p=0.008,120 \mathrm{mg} / \mathrm{kg}$ group, $9.98 \pm 6.95 \mathrm{nmol} / \mathrm{ml}, p=0.0001,240$ $\mathrm{mg} / \mathrm{kg}$ group, $11.11 \pm 9.17 \mathrm{nmol} / \mathrm{ml}, p=0.0003$ ) and $\mathrm{H}_{2} \mathrm{O}_{2}$ (control group, $67.84 \pm 36.43 \mathrm{mmol} / \mathrm{L}, 120 \mathrm{mg} / \mathrm{kg}$ group, $42.44 \pm 12.26 \mathrm{mmol} / \mathrm{L}, p=0.042$ ) decreased but that of SOD (control group, $148.47 \pm 24.8 \mathrm{U} / \mathrm{ml}, 60$ $\mathrm{mg} / \mathrm{kg}$ group, $169.35 \pm 20.92 \mathrm{U} / \mathrm{ml}, p=0.041,120 \mathrm{mg} / \mathrm{kg}$ group, $173.78 \pm 29.33 \mathrm{U} / \mathrm{ml}, p=0.036)$ increased under acute hypoxia following treatment with various doses of NBP (Figure 7B-D). Under chronic hypoxia, levels of MDA (control group, $8.84 \pm 2.06 \mathrm{nmol} / \mathrm{ml}, 120 \mathrm{mg} / \mathrm{kg}$ group, $5.88 \pm 1.75 \mathrm{nmol} / \mathrm{ml}$, $p=0.002,240 \mathrm{mg} / \mathrm{kg}$ group, $4.86 \pm 1.27 \mathrm{nmol} / \mathrm{ml}, p=0.00003$ ) and $\mathrm{H}_{2} \mathrm{O}_{2}$ (control group, $351.13 \pm 111.57$ $\mathrm{mmol} / \mathrm{L}, 120 \mathrm{mg} / \mathrm{kg}$ group, $245.28 \pm 76.66 \mathrm{mmol} / \mathrm{L}, p=0.024$ ) decreased, but GSH-Px expression was upregulated (control group, $457.01 \pm 326.03 \mathrm{U} / \mathrm{mg}$ protein, $120 \mathrm{mg} / \mathrm{kg}$ group, $976.35 \pm 462.23 \mathrm{U} / \mathrm{mg}$ protein, $p=0.031,240 \mathrm{mg} / \mathrm{kg}$ group, $1210.58 \pm 294.57 \mathrm{U} / \mathrm{mg}$ protein, $p=0.001$ ) (Figure 8B, D, F). Thus, NBP may increase the antioxidant capacity and exert opposite effects on oxidant capacity. The content of ATP (control group, $686.55 \pm 129.51 \mu \mathrm{mol} / \mathrm{g}$ protein, $60 \mathrm{mg} / \mathrm{kg}$ group, $1228.51 \pm 364.34 \mu \mathrm{mol} / \mathrm{g}$ protein, $p=0.031$ ) significantly increased under chronic hypoxia (Figure $8 \mathrm{~A}$ ) and lactate level significantly decreased under acute (control group, $32.79 \pm 8.63 \mathrm{mmol} / \mathrm{L}, 240 \mathrm{mg} / \mathrm{kg}$ group, $16.83 \pm 13.14 \mathrm{mmol} / \mathrm{L}$, $p=0.002$ ) and chronic hypoxia (control group, $23.5 \pm 13.03 \mathrm{mmol} / \mathrm{L}, 60 \mathrm{mg} / \mathrm{kg}$ group, $13.38 \pm 5.15 \mathrm{mmol} / \mathrm{L}$, $p=0.028,120 \mathrm{mg} / \mathrm{kg}$ group, $8.9 \pm 5.01 \mathrm{mmol} / \mathrm{L}, p=0.004,240 \mathrm{mg} / \mathrm{kg}$ group, $12.48 \pm 8.65 \mathrm{mmol} / \mathrm{L}, p=0.047$ ) (Figure 7E and $8 \mathrm{E}$ ). These observations suggest NBP promoted ATP production via oxidative phosphorylation instead of glycolysis. NBP at $240 \mathrm{mg} / \mathrm{kg}$ dose significantly decreased red blood cell $(p=0.01)$, hemoglobin $(p=0.004)$, and platelet counts $(p=0.002)$ as well as hematocrit level $(p=0.028)$ under acute hypoxia (Table S1). NBP significantly increase white blood cell count at $60 \mathrm{mg} / \mathrm{kg}$ concentration ( $p=0.047)$ and decreased platelet count at $120 \mathrm{mg} / \mathrm{kg}$ concentration $(p=0.042)$ under chronic hypoxia (Table S2).

3.3. NBP improved learning and memory ability under acute and chronic hypoxia

The cognition functions of rats were evaluated through the shuttle-box experiment. Under acute hypoxia, $\mathrm{NBP}$ at $240 \mathrm{mg} / \mathrm{kg}$ doses could significantly increase times of active escape (control group, $1.44 \pm 1.5 \mathrm{~s}$, $240 \mathrm{mg} / \mathrm{kg}$ group, $3.13 \pm 2.17 \mathrm{~s}, p=0.035$ ) (Figure 9). However, NBP had no effect on average time of active escape. The beneficial effect of NBP on learning and memory function was not as consistent as that on physical activity. Furthermore, MDA, SOD, $\mathrm{H}_{2} \mathrm{O}_{2}$, and $\mathrm{GSH}-\mathrm{Px}$ levels were analyzed in animal blood samples. The level of $\mathrm{H}_{2} \mathrm{O}_{2}$ (control group, $155.7 \pm 89.57 \mathrm{mmol} / \mathrm{L}, 60 \mathrm{mg} / \mathrm{kg}$ group, $77.61 \pm 37.14 \mathrm{mmol} / \mathrm{L}$, $p=0.041,120 \mathrm{mg} / \mathrm{kg}$ group, $75.59 \pm 33.71 \mathrm{mmol} / \mathrm{L}, p=0.035,240 \mathrm{mg} / \mathrm{kg}$ group, $74.64 \pm 35.19 \mathrm{mmol} / \mathrm{L}$, $p=0.046$ ) decreased and the expression of GSH-Px (control group, 5999.26 $\pm 659.23 \mathrm{U} / \mathrm{mg}$ protein, 240 
$\mathrm{mg} / \mathrm{kg}$ group, $6704.55 \pm 451.45 \mathrm{U} / \mathrm{mg}$ protein, $p=0.033$ ) was upregulated under acute hypoxia (Figure $11 \mathrm{C}-\mathrm{D}$ ). Under chronic hypoxia, the levels of MDA (control group, $11.51 \pm 5.71 \mathrm{nmol} / \mathrm{ml}, 120 \mathrm{mg} / \mathrm{kg}$ group, $7.05 \pm 1.47 \mathrm{nmol} / \mathrm{ml}, p=0.028$ ) and $\mathrm{H}_{2} \mathrm{O}_{2}$ (control group, $274.27 \pm 78.84 \mathrm{mmol} / \mathrm{L}, 120 \mathrm{mg} / \mathrm{kg}$ group, $200.67 \pm 47.33 \mathrm{mmol} / \mathrm{L}, p=0.029)$ decreased (Figure 12A, C). Thus, NBP could also increase the antioxidant capacity and decrease the oxidant capacity in animals.

\section{Discussion}

High altitude is characterized with decline in air pressure and partial oxygen pressure. Physical and cognitive functions may be severely affected following exposure to high altitude. However, the number of people staying at high altitude is increasing and their work performance and daily life are greatly affected by high altitude. Therefore, there is an urgent need to develop methods that alleviate physical and cognitive impairments at high altitude under hypobaric hypoxia environment.

Several studies have demonstrated that NBP ameliorates ischemic injury and promotes neuroplasticity and recovery from injury. The therapeutic mechanisms underlying these effects were closely associated with various processes, including anti-oxidant, anti-inflammation, angiogenesis, anti-thrombosis, neurogenesis and metabolic reprogramming. Our previous results have shown that the effects of NBP on hypobaric hypoxia were mainly related to anti-oxidant properties and metabolic reprogramming. The failure of human physiological responses to hypobaric hypoxia may result in increased inflammation, oxidative stress, and metabolic adjustment. Our study found that exposure to high altitude resulted in upregulation in the expression of inflammatory cytokines and downregulation anti-inflammatory cytokines expression [7]. Moreover, hypobaric hypoxia induces oxidative damage and decreases antioxidative functions [20]. Considering metabolic modulation, glycolytic capacity is promoted and oxidative metabolism is suppressed in response to hypoxia [21,22]. A recent study showed the relationship between oxidative stress and accelerated cognitive decline in chronic mountain sickness [23], suggesting that these molecular changes induced by hypobaric hypoxia may lead to behavioral abnormality. Given the effect of NBP on rodents with hypobaric hypoxia, we conclude that NBP reverses the alteration in hypoxia-induced oxidative stress and metabolism, thereby possibly reversing physical and learning and memory changes. Whether NBP could improve the effect of hypoxia on inflammation warrants further studies.

The effect and mechanism of acute and chronic hypoxia on human and animals showed remarkable difference [24-27], and treatment for reducing damage or diseases from acute and chronic hypoxia also showed great discrepancy. However, in this work, the effect of NBP did not exhibit obvious difference between acute and chronic hypoxia. There could be common mechanism of acute and chronic hypoxia on bodies, and some therapies and agents, such as NBP, could improve abilities under both acute and chronic hypoxia. Moreover, the effects of hypoxia on the brain showed region-specific character [28,29], we studied the effect of NBP on a common declined ability-learning and memory function [30,31] to evaluate the role of this agent on cognitive ability. And the effect of NBP on other cognitive function under hypobaric hypoxia remains to be investigated. 
While NBP played an important role in improving physical and learning and memory functions of animals under hypobaric hypoxia, it would be interesting to assess the effects of NBP on diverse cognitive functions at high-altitude (and after). However, the administrative dosage was relatively higher than that employed in other studies. Therefore, it is imperative to improve the role of NBP and develop new therapeutics for reducing hypobaric hypoxia-induced physical and cognitive decline.

\section{Conclusion}

In summary, we demonstrate the NBP-mediated improvement in physical and learning and memory of rodents under acute and chronic hypobaric hypoxia, as evident from the elevation in the anti-oxidative functions and promotion of oxidative phosphorylation instead of glycolysis.

\section{Abbreviations}

BW: body weight

GSH-Px: glutathione peroxidase

$\mathrm{H}_{2} \mathrm{O}_{2}$ : hydrogen peroxide

KM: Kunming

MDA: malonaldehyde

NBP: DL-3-n-butylphthalide

SD: Sprague-Dawley

SOD: superoxide dismutase

ST: survival time

STT: standard hypoxia tolerance time

V: volume

\section{Declarations}

\section{Availability of data and materials}

Not applicable.

\section{Acknowledgement}

\section{Funding}


This research was supported by grants from National Science and Technology Major Project (2014ZX09J14102-05B and 2018ZX09J18109).

\section{Authors' information}

\section{Affiliation}

GX, YS, BS, LL, GE, SH, JZ, BL, QH, JC, YG, EZ, Institute of Medicine and Equipment for High Altitude Region, College of High Altitude Military Medicine, Army Medical University, Chongqing, China.

\section{Author contributions}

GX performed experiments, interpreted the data, and wrote the manuscript. YS, BS, GE, and QH raised animals and performed animal experiments. LL, SH, and JZ participated in experiments of blood samples. BL and JC participated in data analysis and manuscript writing. YG and EZ conceived the study design, experimental plan, and manuscript writing. All authors discussed the results and critically reviewed the manuscript.

\section{Corresponding author}

Correspondence to $\mathrm{YG}$ and $\mathrm{EZ}$.

\section{Ethics Declarations}

Ethics approval and consent to participate

Not applicable.

\section{Consent for publication}

All co-authors have read and approved of its submission to this journal.

\section{Conflict of interest statement}

The authors have no conflict of interest.

\section{References}

1. Yan X. Cognitive impairments at high altitudes and adaptation. High Alt Med Biol. 2014;15(2):141-5.

2. Zhang G, Zhou SM, Zheng SJ, Liu FY, Gao YQ. Astragalus on the anti-fatigue effect in hypoxic mice. Int J Clin Exp Med. 2015;8(8):14030-5.

3. Lague SL. High-altitude champions: birds that live and migrate at altitude. J Appl Physiol. 2017;123(4):942-50. 
4. Naeije R. Physiological adaptation of the cardiovascular system to high altitude. Prog Cardiovasc Dis. 2010;52(6):456-66.

5. Taylor AT. High-altitude illnesses: physiology, risk factors, prevention, and treatment. Rambam Maimonides Med J. 2011;2(1):e0022.

6. Basnyat B, Murdoch DR. High-altitude illness. Lancet. 2003;361(9373):1967-74.

7. Liu B, Chen J, Zhang L, Gao Y, Cui J, Zhang E, et al. IL-10 dysregulation in acute mountain sickness revealed by transcriptome analysis. Front Immunol. 2017;8:628.

8. Liao WT, Liu B, Chen J, Cui JH, Gao YX, Liu FY, et al. Metabolite modulation in human plasma in the early phase of acclimatization to hypobaric hypoxia. Sci Rep. 2016;6:22589.

9. Dosek A, Ohno H, Acs Z, Taylor AW, Radak Z. High altitude and oxidative stress. Respir Physiol Neurobiol. 2007;158(2-3):128-31.

10. Liu CL, Liao SJ, Zeng JS, Lin JW, Li CX, Xie LC, et al. dl-3n-butylphthalide prevents stroke via improvement of cerebral microvessels in RHRSP. J Neurol Sci. 2007;260(1-2):106-13.

11. Wang S, Ma F, Huang L, Zhang Y, Peng Y, Xing C, et al. DI-3-n-Butylphthalide (NBP): a promising therapeutic agent for ischemic stroke. CNS Neurol Disord Drug Targets. 2018;17(5):338-47.

12. Niu XL, Jiang X, Xu GD, Zheng GM, Tang ZP, Yin N, et al. DL-3-n-butylphthalide alleviates vascular cognitive impairment by regulating endoplasmic reticulum stress and the Shh/Ptch1 signalingpathway in rats. J Cell Physiol. 2019;234(8):12604-14.

13. Sun $Y$, Cheng $X$, Wang H, Mu X, Liang Y, Luo Y, et al. dl-3-n-butylphthalide promotes neuroplasticity and motor recovery in stroke rats. Behav Brain Res. 2017;329:67-74.

14. Min JJ, Huo XL, Xiang LY, Qin YQ, Chai KQ, Wu B, et al. Protective effect of DI-3n-butylphthalide on learning and memory impairment induced by chronic intermittent hypoxia-hypercapnia exposure. Sci Rep. 2014;4:5555.

15. Lu G, Ding D, Shi M. Acute adaptation of mice to hypoxic hypoxia. Biol Signals Recept. 1999;8(45):247-55.

16. Xu G, Gao YQ, Gao YX, Wu G, Zhang JY, Gao WX. An improved formula for standard hypoxia tolerance time (STT) to evaluate hypoxic tolerance in mice. Mil Med Res. 2018;5(1):33.

17. Zaretsky DV, Kline H, Zaretskaia MV, Rusyniak DE. Automatic analysis of treadmill running to estimate times to fatigue and exhaustion in rodents. PeerJ. 2018;6:e5017.

18. Wang CC, Ding L, Zhang LY, Shi HH, Xue CH, Chi NQ, et al. A pilot study on the effects of DHA/EPAenriched phospholipids on aerobic and anaerobic exercises in mice. Food Funct. 2020;11(2):1441-54.

19. Hou X, Xu H, Chen W, Zhang N, Zhao Z, Fang X, et al. Neuroprotective effect of dimethyl fumarate on cognitive impairment induced by ischemic stroke. Ann Transl Med. 2020;8(6):375.

20. Irarrazaval S, Allard C, Campodonico J, Perez D, Strobel P, Vasquez L, et al. Oxidative stress in acute hypobaric hypoxia. High Alt Med Biol. 2017;18(2):128-34.

21. Murray AJ. Energy metabolism and the high-altitude environment. Exp Physiol. 2016;101(1):23-7. 
22. Murray AJ, Montgomery HE, Feelisch M, Grocott MPW, Martin DS. Metabolic adjustment to highaltitude hypoxia: from genetic signals to physiological implications. Biochem Soc Trans. 2018;46(3):599-607.

23. Bailey DM, Brugniaux JV, Filipponi T, Marley CJ, Stacey B, Soria R, et al. Exaggerated systemic oxidative-inflammatory-nitrosative stress in chronic mountain sickness is associated with cognitive decline and depression. J Physiol. 2019;597(2):611-29.

24. Lefranois $R$, Gautier $H$, Pasquis P. Ventilatory oxygen drive in acute and chronic hypoxia. Respir Physiol. 1968;4(2):217-28.

25. Bartsch P, Swenson ER. Acute high-altitude illnesses. N Engl J Med. 2013;369(17):1666-7.

26. West JB. Physiological effects of chronic hypoxia. N Engl J Med. 2017;376(20):1965-71.

27. Mazzeo RS, Bender PR, Brooks GA, Butterfield GE, Groves BM, Sutton JR, et al. Arterial catecholamine responses during exercise with acute and chronic high-altitude exposure. Am J Physiol. 1991;261(4 Pt 1):E419-24.

28. Smith SM, Friedle SA, Watters JJ. Chronic intermittent hypoxia exerts CNS region-specific effects on rat microglial inflammatory and TLR4 gene expression. PLoS One. 2013;8(12):e81584.

29. Macri MA, Dalessandro N, Di Giulio C, Di lorio P, Di Luzio S, Giuliani P, et al. Region-specific effects on brain metabolites of hypoxia and hyperoxia overlaid on cerebral ischemia in young and old rats: a quantitative proton magnetic resonance spectroscopy study. J Biomed Sci. 2010;17(1):14.

30. Zhu M, Xu M, Zhang K, Li J, Ma H, Xia G, et al. Effect of acute exposure to hypobaric hypoxia on learning and memory in adult Sprague-Dawley rats. Behav Brain Res. 2019;367:82-90.

31. Qaid E, Zakaria R, Sulaiman SF, Yusof NM, Shafin N, Othman Z, et al. Insight into potential mechanisms of hypobaric hypoxia-induced learning and memory deficit - Lessons from rat studies. Hum Exp Toxicol. 2017;36(12):1315-25.

\section{Table}

Table 1. NBP administration plan for various groups to mice and rats.

\begin{tabular}{|lllll|}
\hline $\begin{array}{l}\text { Drug groups } \\
\text { /Rodents }\end{array}$ & Control $(\mathrm{n}=10)$ & $\begin{array}{l}\text { Low } \\
(\mathrm{n}=10)\end{array}$ & Moderate $(\mathrm{n}=10)$ & High $(\mathrm{n}=10)$ \\
\hline Mouse & $\begin{array}{l}\text { equivalent volume corn } \\
\text { oil }\end{array}$ & $90 \mathrm{mg} / \mathrm{kg}$ & $180 \mathrm{mg} / \mathrm{kg}$ & $120 \mathrm{mg} / \mathrm{kg}$ \\
\hline Rat & $\begin{array}{l}\text { equivalent volume corn } \\
\text { oil }\end{array}$ & $60 \mathrm{mg} / \mathrm{kg}$ & $120 \mathrm{mg} / \mathrm{kg}$ & $240 \mathrm{mg} / \mathrm{kg}$ \\
\hline
\end{tabular}

\section{Figures}




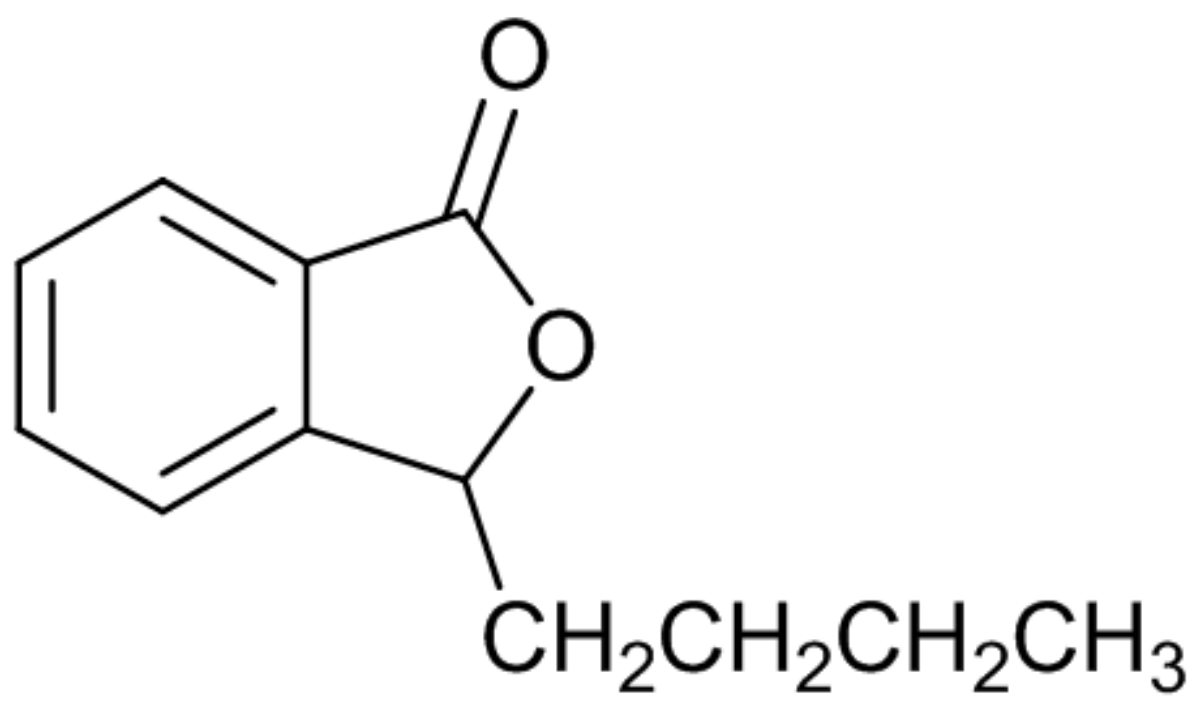

Figure 1

Structure of DL-3-n-butylphthalide.

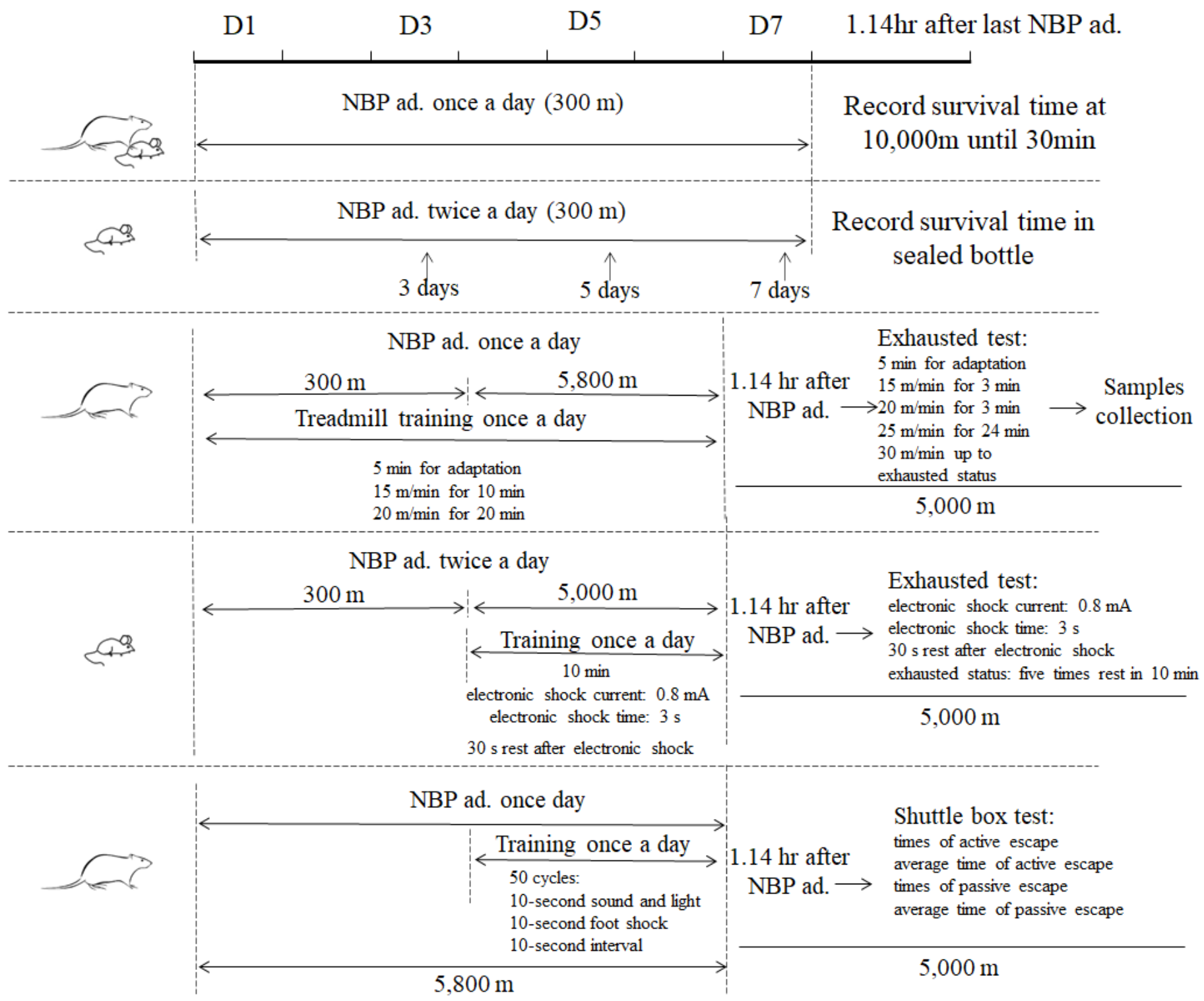


Figure 2

Illustration of hypoxia tolerance experiments and experiments under acute hypoxia. (1) Acute hypoxia survival experiment in 10,000 m hypobaric hypoxia chamber; (2) Standard hypoxia tolerance experiment of mice; (3) Treadmill running experiment for acute hypoxic rats; (4) Motor-driven wheel-track treadmill fatigue experiments for acute hypoxic mice; (5) Shuttle-box experiment for acute hypoxic rats.

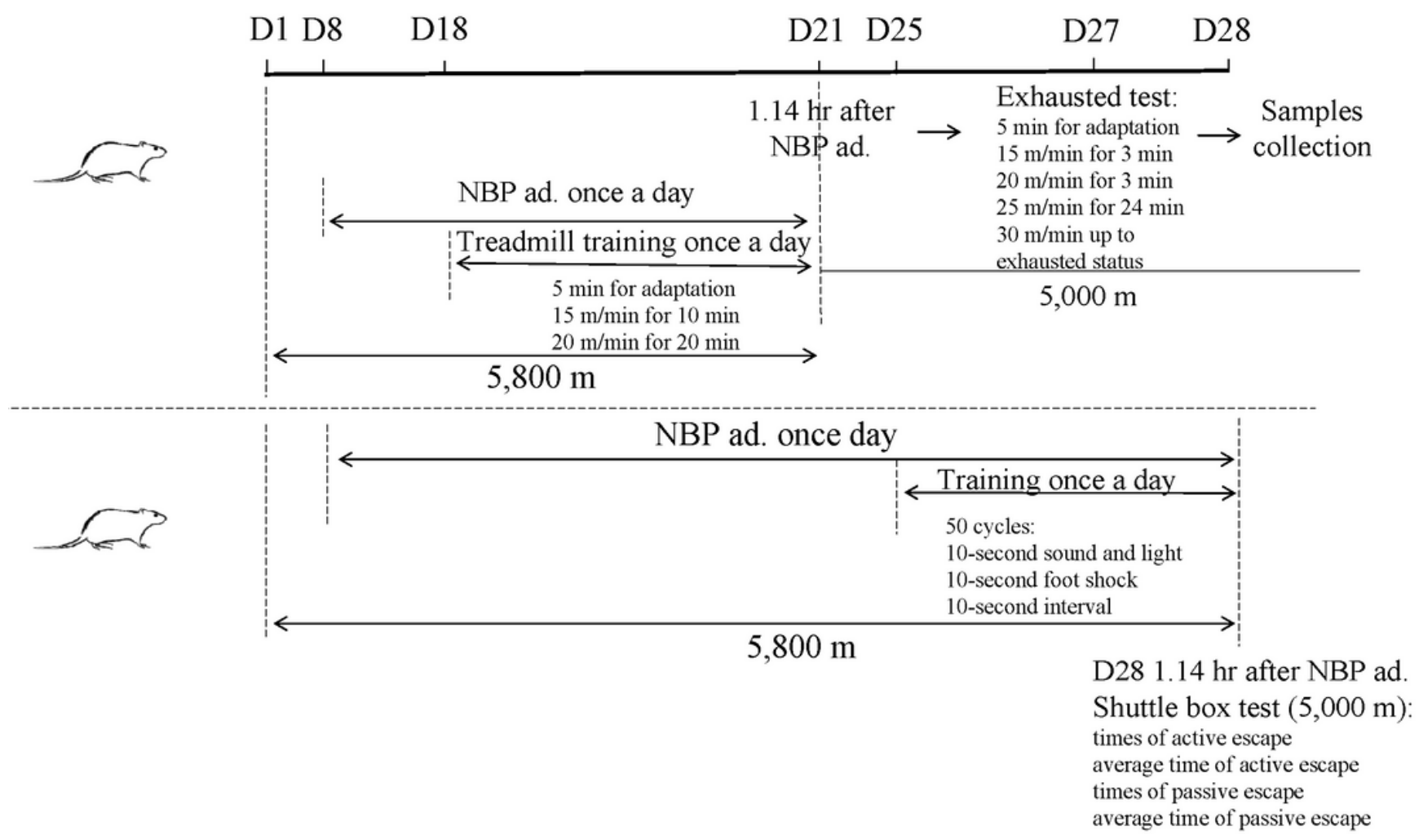

(6)

\section{Figure 3}

Illustration of experiments under chronic hypoxia. (6) Treadmill running experiment for chronic hypoxic rats; (7) Shuttle-box experiment for chronic hypoxic rats.
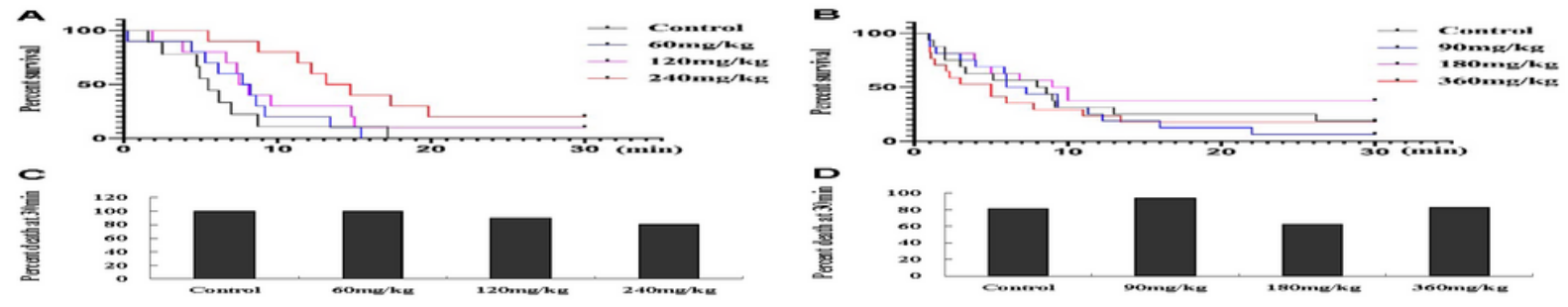
Figure 4

Survival analysis of rats and mice with administration of NBP at 10,000 m exposure. The survival curve of rats (A) and mice (B) at 10,000 m exposure after NBP administration for 7 days with 30 min as stopped time. The death percentage of rats (C) and mice (D) after 30 min exposure at 10,000 m.
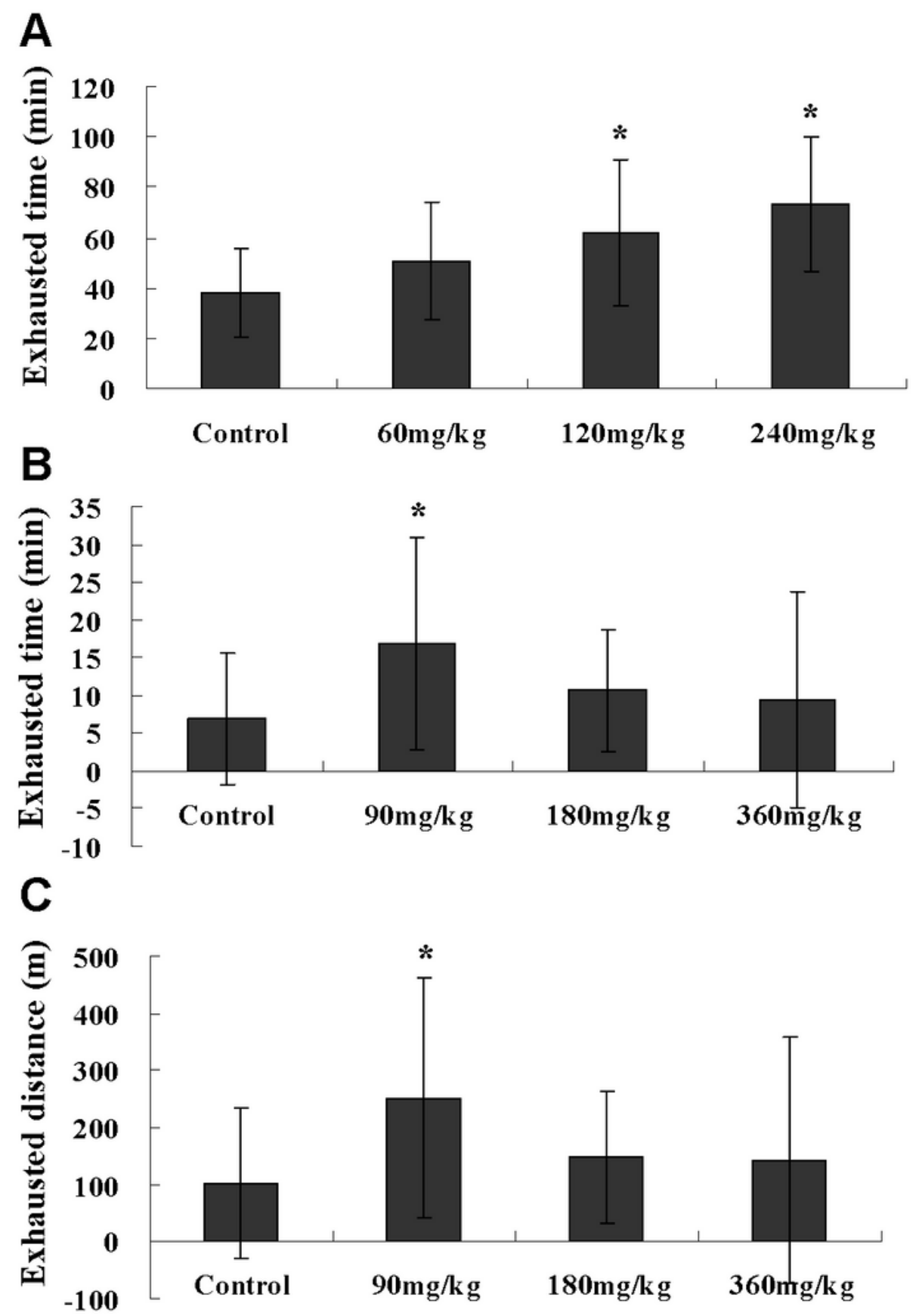

Figure 5 
Effects of NBP on the exhausted motor of rats and mice under acute hypoxia. (A) Exhausted time of rats in treadmill running experiment at $5,800 \mathrm{~m}$ for 3 days. Exhausted time (B) and exhausted distance (C) of mice in forced exercise wheel-track treadmill experiment at 5,000 $\mathrm{m}$ for 1 day. ${ }^{*}, p<0.05 \mathrm{vs}$. control group. Figure 6. Effects of NBP on the exhausted motor of rats under chronic hypoxia. Exhausted time of rats in treadmill running experiment at $5,800 \mathrm{~m}$ for 21 days. ${ }^{*}, p<0.05 \mathrm{vs}$. control group.

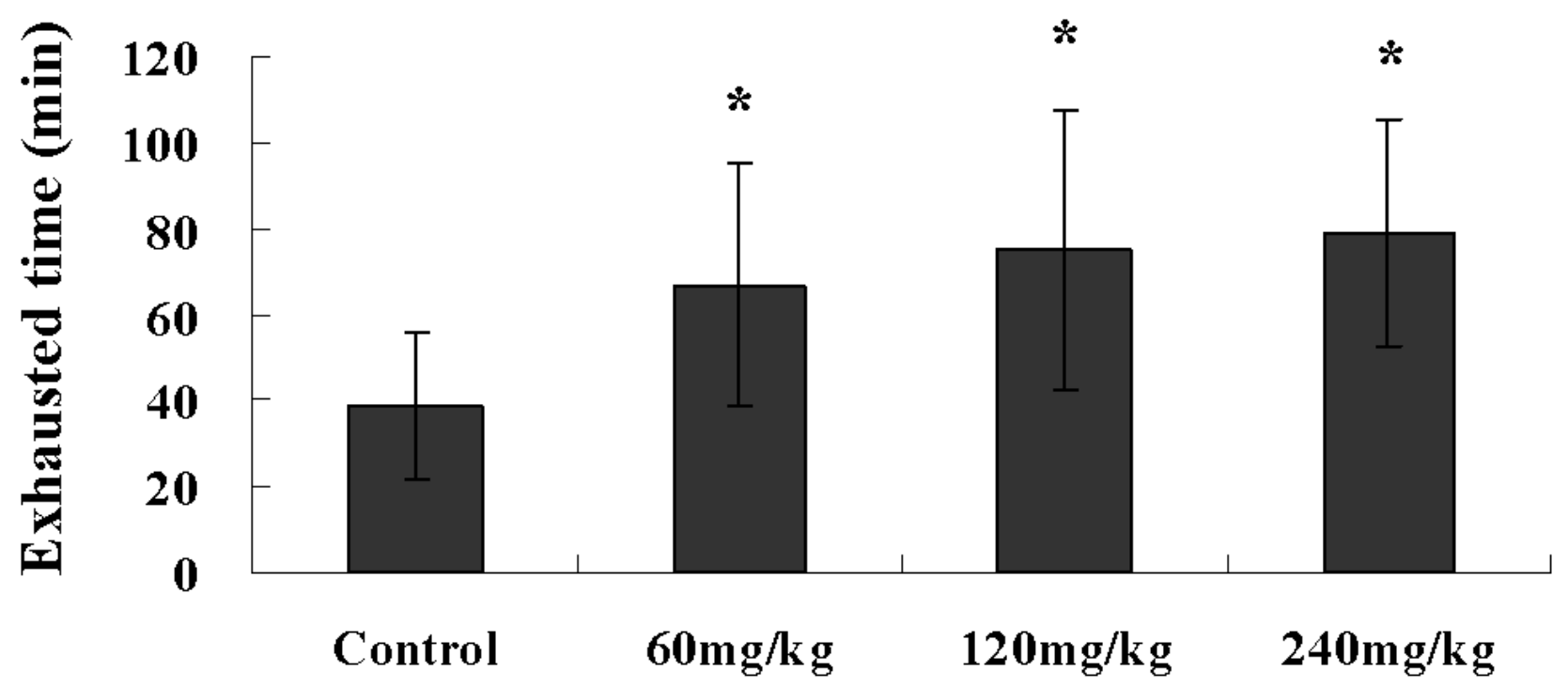

Figure 6

Effects of NBP on the exhausted motor of rats under chronic hypoxia. Exhausted time of rats in treadmill running experiment at $5,800 \mathrm{~m}$ for 21 days. ${ }^{\star}, \mathrm{p}<0.05 \mathrm{vs}$. control group. 
A
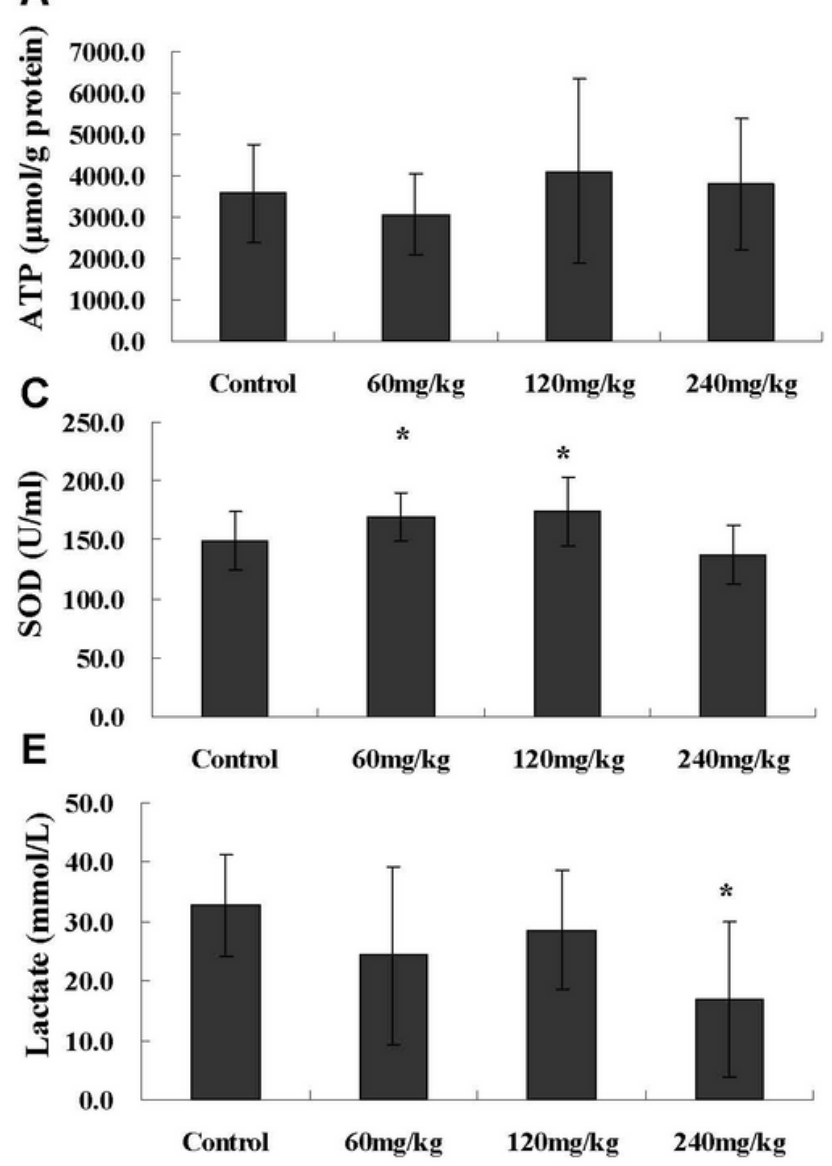

B
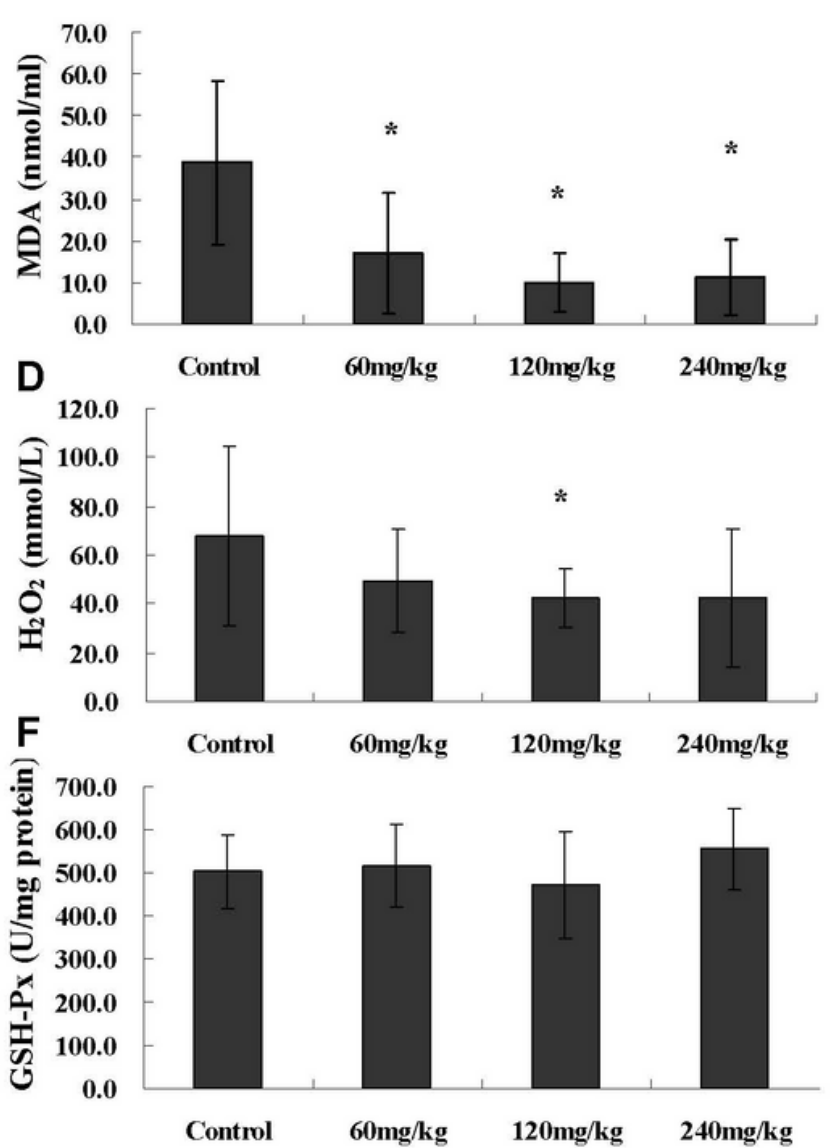

Figure 7

Effects of NBP on the energy metabolism and oxidative stress of exhausted rats under acute hypoxia. ATP level in the gastrocnemius muscle (A) and MDA (B), SOD (C), H2O2 (D), lactate (E), and GSH-Px (F) levels in the serum were detected. ${ }^{*}, p<0.05$ vs. control group. 
A

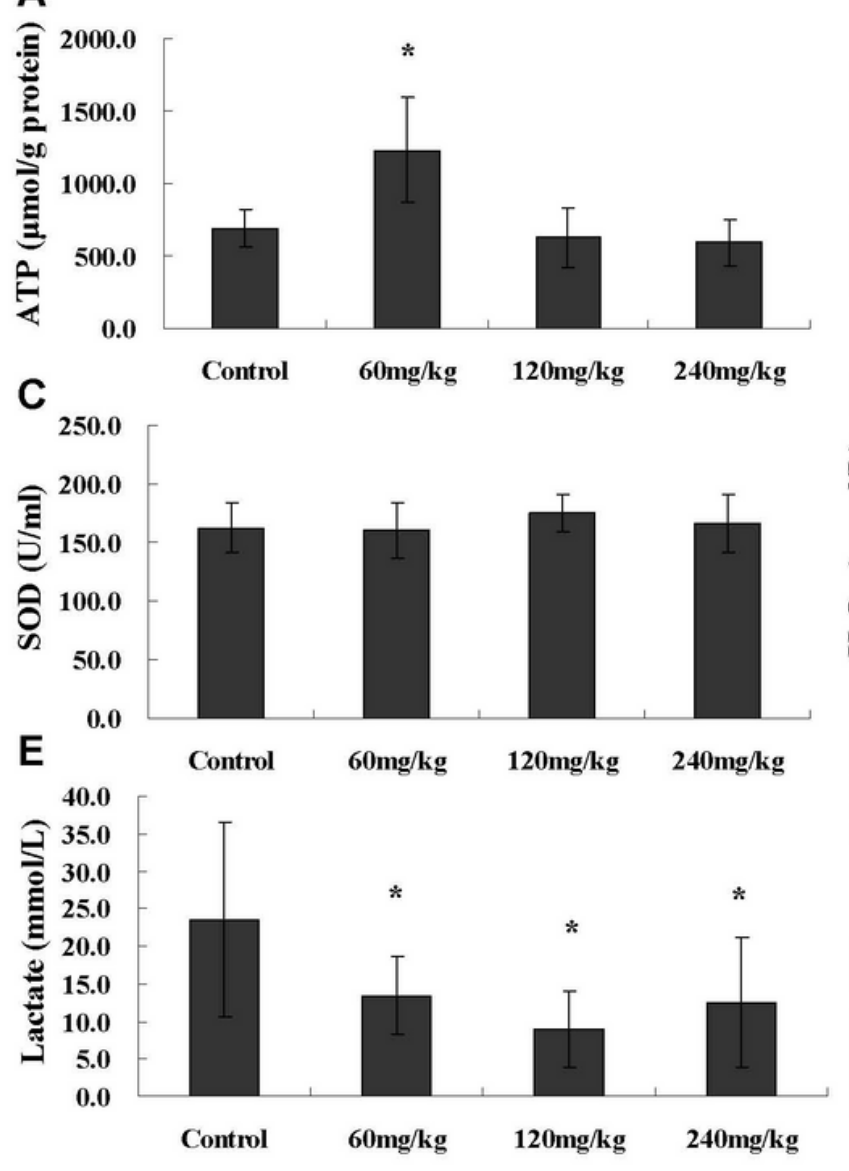

B
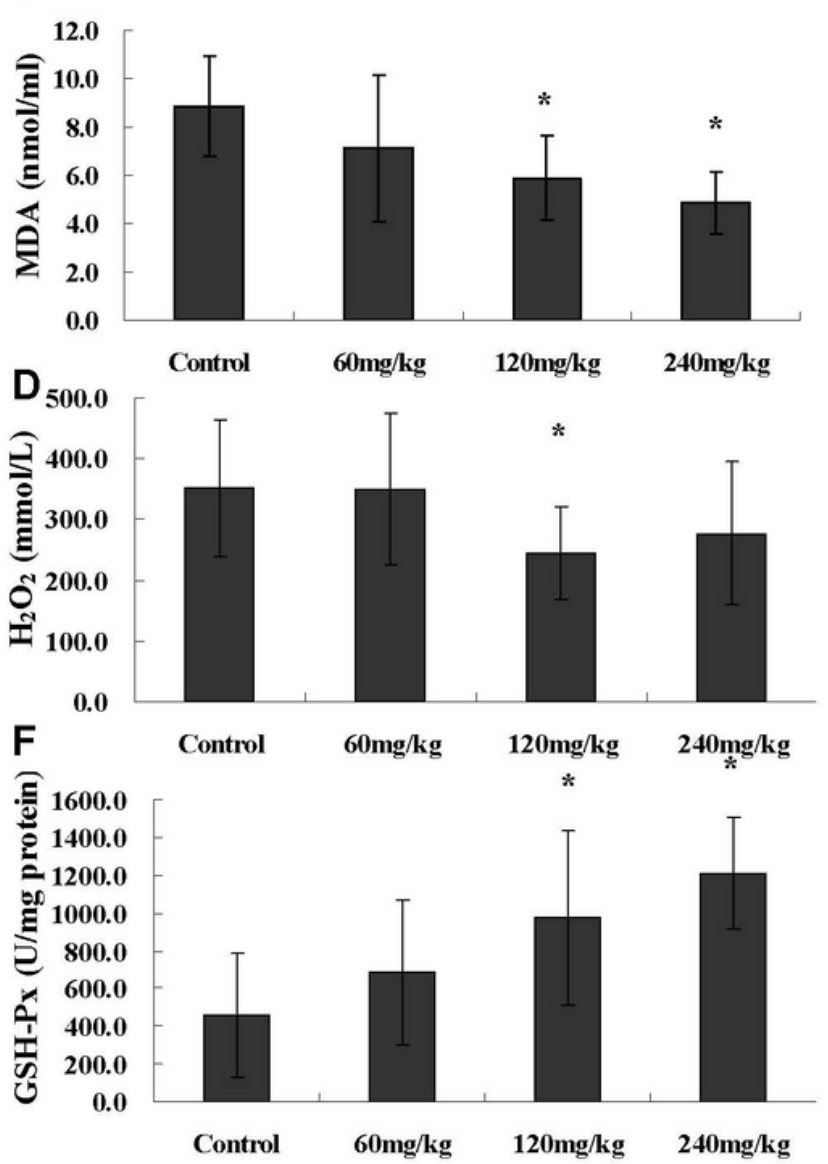

\section{Figure 8}

Effects of NBP on the energy metabolism and oxidative stress of exhausted rats under chronic hypoxia. ATP level in the gastrocnemius muscle (A) and MDA (B), SOD (C), H2O2 (D), lactate (E), and GSH-Px (F) levels in the serum were detected. ${ }^{*}, p<0.05$ vs. control group. 
A
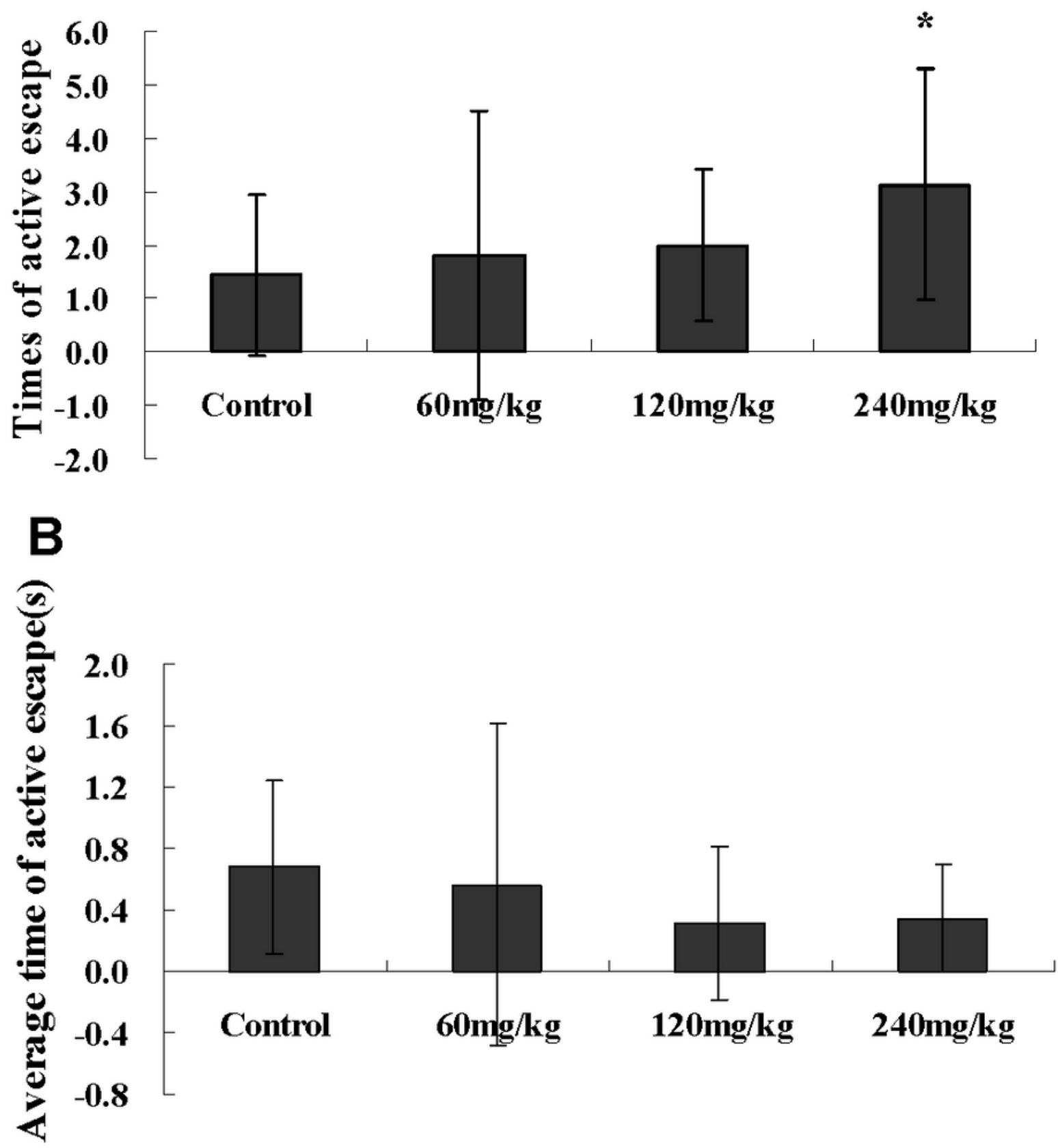

Figure 9

Effects of NBP on rats under acute hypoxia in shuttle-box experiment. Times of active escape $(A)$ and average time of active escape (B) for rats at $5,800 \mathrm{~m}$ for 7 days in the shuttle box experiments. *, $p<0.05$ vs. control group. 
A

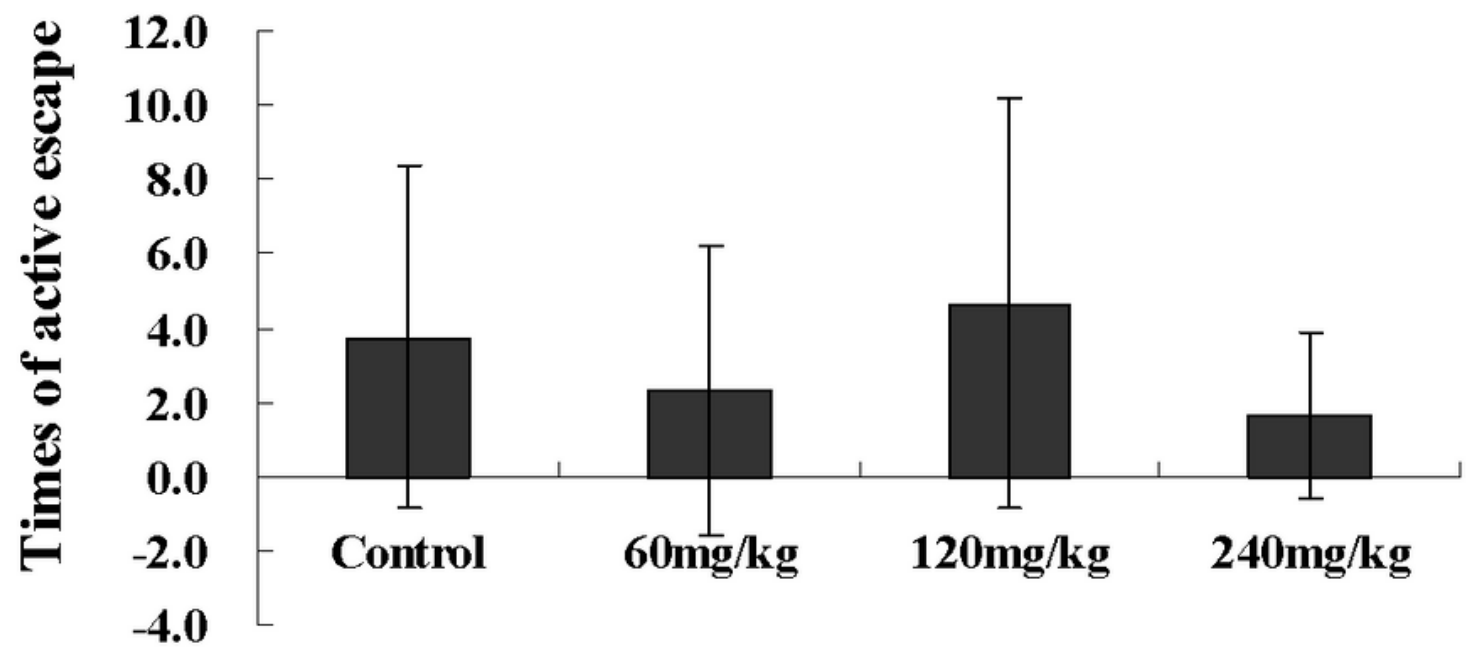

B

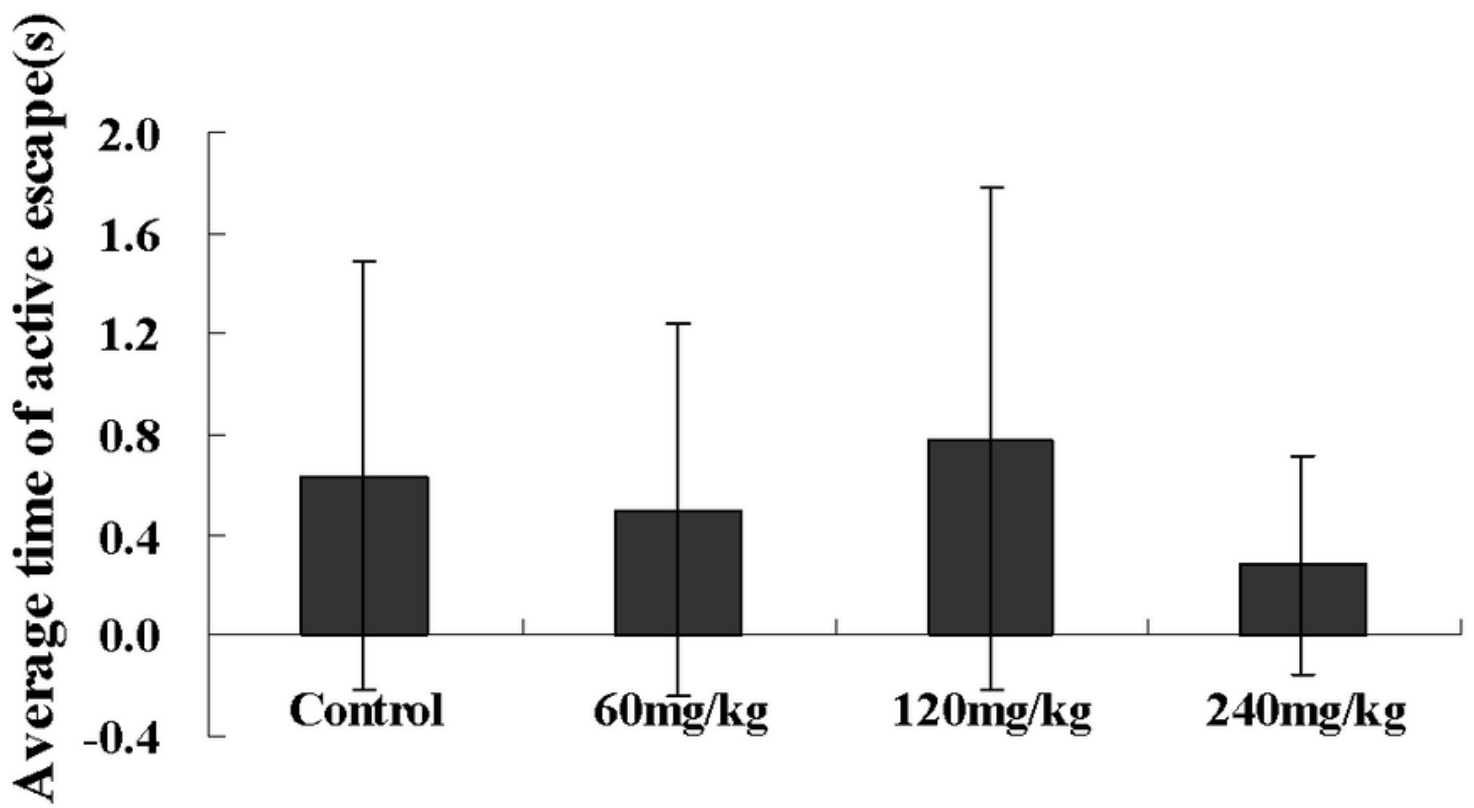

Figure 10

Effects of NBP on rats under chronic hypoxia in shuttle-box experiment. Times of active escape (A) and average time of active escape (B) for rats at $5,800 \mathrm{~m}$ for 28 days in shuttle-box experiments. ${ }^{*}, p<0.05$ vs. control group. 
A

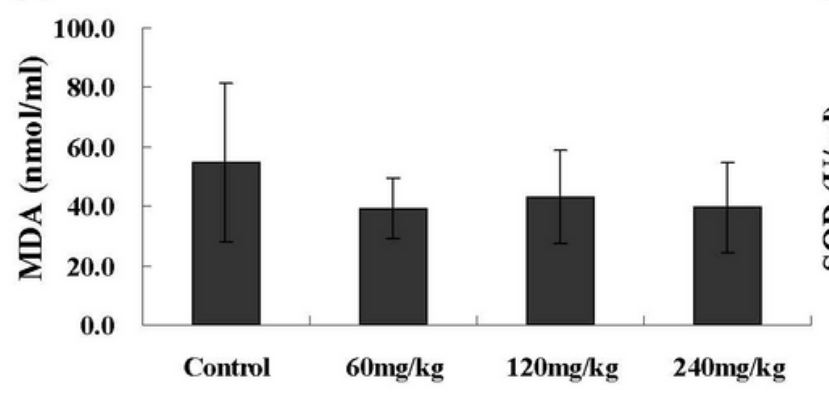

C

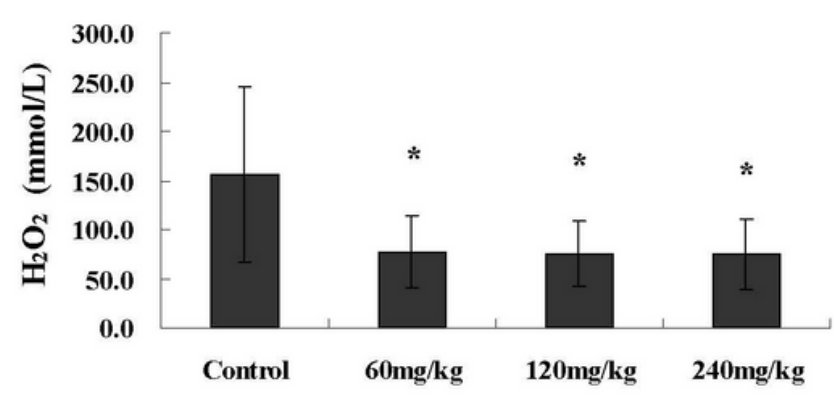

B

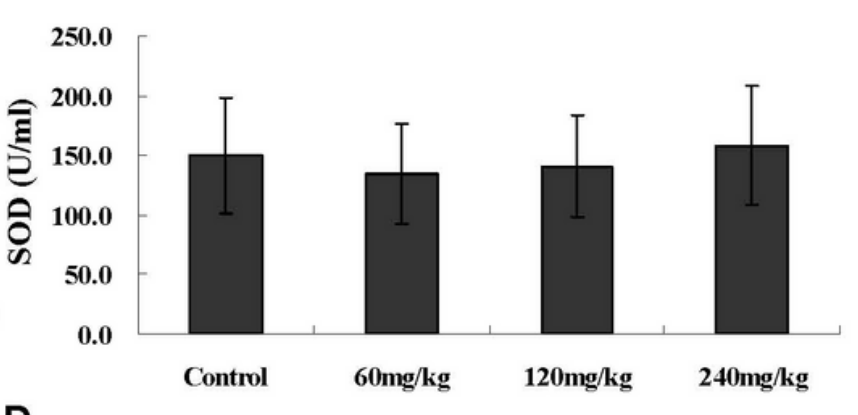

D

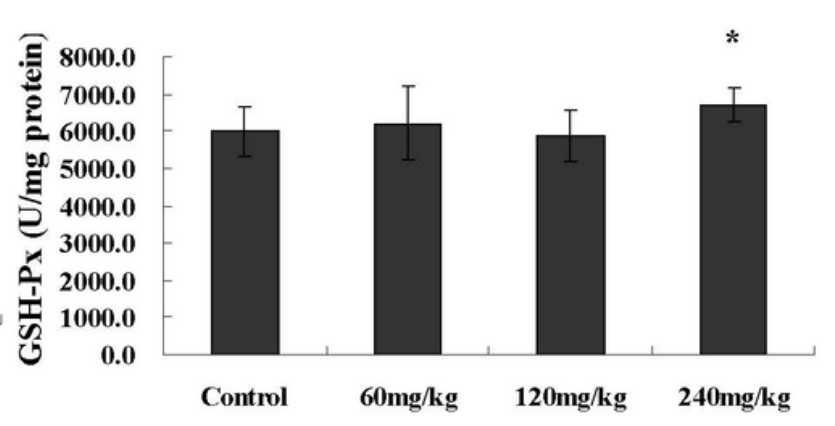

Figure 11

Effects of NBP on the oxidative stress of rats under acute hypoxia after shuttle-box experiment. Levels of $\operatorname{MDA}(A), \operatorname{SOD}(B), \mathrm{H} 2 \mathrm{O} 2(\mathrm{C})$, and GSH-Px (D) in the serum were detected. *, $\mathrm{p}<0.05$ vs. control group. 

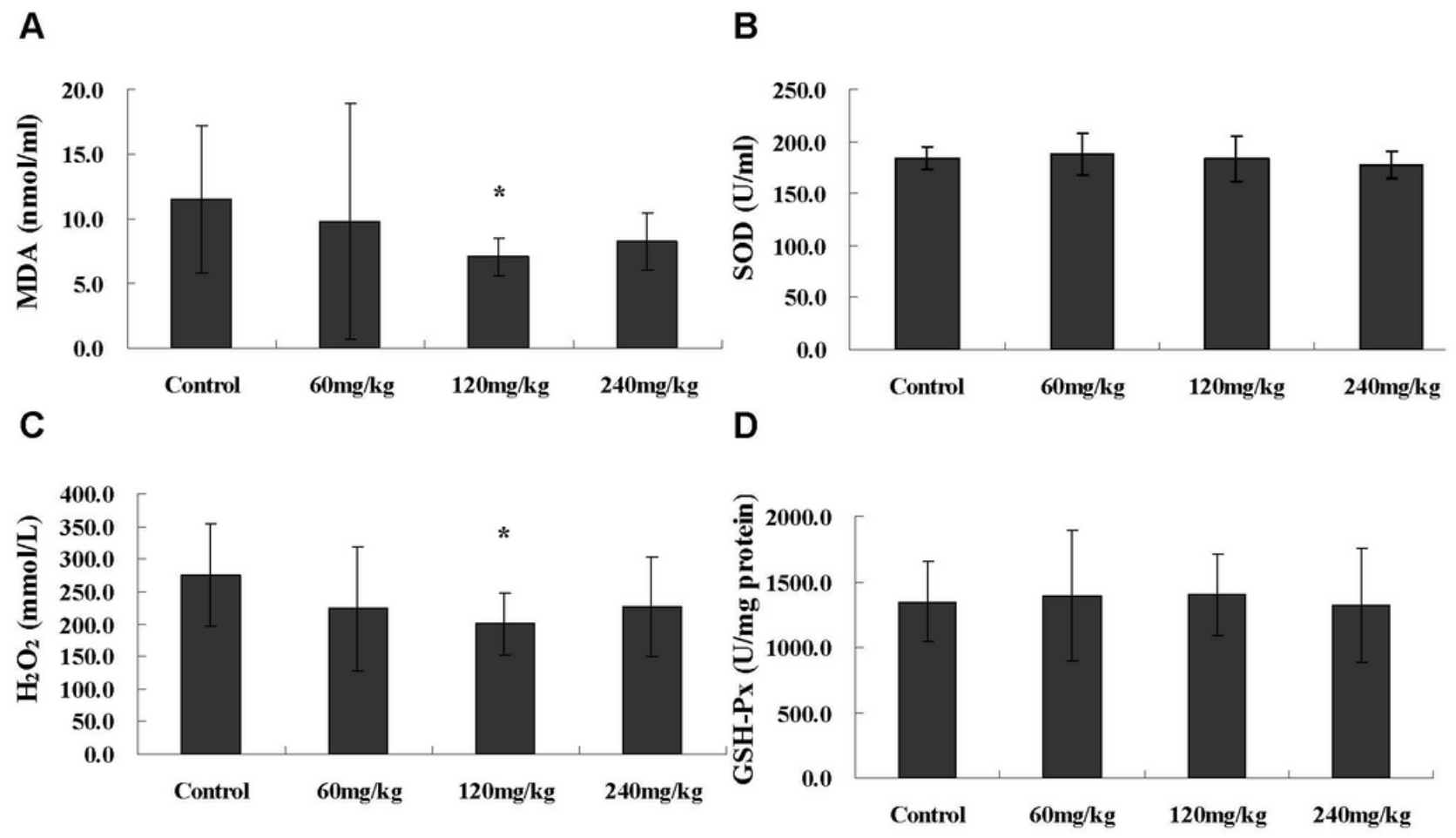

Figure 12

Effects of NBP on the oxidative stress of rats under chronic hypoxia after shuttle-box experiment. Levels of MDA (A), SOD (B), H2O2 (C), and GSH-Px (D) in the serum were detected. *, p<0.05 vs. control group.

\section{Supplementary Files}

This is a list of supplementary files associated with this preprint. Click to download.

- CertificateofeditingHMET01.pdf

- Supplementarylegend.docx

- Supplementarytable.doc

- Fig.S1.tif 